\title{
An Investigation of Pragmatic Functions and Position of Prevalent Persian Discourse Markers Used in Casual Conversations among Tehrani Speakers
}

\author{
Manizheh Alami \\ English Language Center, Salalah College of Technology \\ Salalah, Sultanate of Oman \\ Email: manizheh.alami@yahoo.com
}

Received: 17-07-2015

Published: 01-01-2016
Accepted: 25-10-2015

doi:10.7575/aiac.ijalel.v.5n.1p.250
Advance Access Published: October 2015

URL: http://dx.doi.org/10.7575/aiac.ijalel.v.5n.1p.250

\begin{abstract}
Given that a systematic treatment of Persian Discourse Markers (hereafter DMs) is almost absent in modern Persian linguistics and to bridge this gap, the audio-recorded data comprising 14 face to face casual conversations involving two-party and multi-party interactions among family members, acquaintances and close friends are used to shed light on these 'frequently used' but 'frequently unnoticed' linguistic elements. To document a list of the most common DMs typically used in Tehrani dialect of Persian language and to have a detailed description of their discoursal functions in talk, Brinton's (1996) binary classification of DMs functions (textual and interpersonal) was developed to provide an empirically-supported account of the functions and position of Persian DMs in interaction among Tehrani speakers. The present account of DMs which is basically 'analytical description' provides the reader with the knowledge about how Persian DMs operate in actual usage. The findings are built upon a 3105-word corpus including 14 audio-recorded conversations among 50 participants. Altogether 34 tokens of Persian DMs with an overall 254 occurrences were identified among which na/na baba (no/no daddy) with the total of 33 (12.84\%) occurrences were the most frequently used Persian DM in the data which are followed by dige (no English equivalent), aare/ba'ale (yep/yes), yani (I mean), vali (but), haalaa/ alaan (now), bebin/nega kon (look) and aslan (by no means/ never).To the author, research on the functions and distributional patterns of Persian DMs will broaden our knowledge of their discoursal behavior in language in general and contribute to the already growing cross-linguistic body of work on DMs.
\end{abstract}

Keywords: Discourse Markers, Persian language, Textual function, Interpersonal function, Casual conversation

\section{Introduction}

Recently, studies on spoken language in real-life contexts increased dramatically. As a result, some of the features previously considered 'empty', 'superfluous' and redundant- such as sort of, y'know and well (Goddardand Meanpatterson, 2000, p. 98) now are considered as crucial aspects of interpersonal communication (Alami, 2015). These expressions called 'discourse markers' (Schiffrin, 1987) or 'pragmatic expressions' (Fraser, 1999) have been of "substantial interest to researchers studying situated language use because of their role in demarcating discourse connections as well as their potential for indexing social relationships" (Bolden, 2008, p. 102). Quirk et al. (1985) calls DMs "sharing devices" and "intimacy signals", whereas to Brinton (2008, p. 1) DMs are "phonologically short items that have no or little referential meaning but serve pragmatic or procedural purpose". According to Blakemore's relevance oriented definition (cited in Muller, 2005, p. 9), "DMs guide the hearer in finding the most relevant interpretation in the given context by constraining the number of possible interpretations." Redeker (1991, p. 367-381) sees DMs as lexical equivalents or complements for elusive gestural or intonation cues that contribute to the participant's comprehension. For Stenstrom (1994, p. 17) a conversation is "much less lively and less personal without DMs". Believing that DMs do not contribute anything to the propositional content in the context where they appear, Lenk (1998) states that although the propositional content of a sentence/utterance might not be altered by the addition or deletion of DMs, they perform an important pragmatic function in the interaction.

In sum, DMs are contextually sensitive lexical items utilized to structure discourse. They link the stretches of discourse together, mark discourse coherence restrict the scope of the hearer's interpretation of the discourse and signal the relationship between the speaker and hearer as well as the relations among different parts of the discourse.

\section{Statement of the Problem}

Assuming that all languages make use of DMs or similar devices, the main concern of the present study is to answer the questions 'which lexical items are used as DMs in spoken Persian and what functions they have in spoken discourse. As the study on Persian DMs has been relatively ignored to date, the current study aims to conduct an empirical analysis of DMs used by Persian speakers in casual, daily conversations in order to fill the void. 


\section{Objectives of the Study}

The present study pursues the following aims:

1. To identify the commonly used lexical items that function as DMs in Persian casual conversation.

2. To investigate the pragmatic functions of Persian DMs in the interpersonal and textual domains.

3. To specify the position of Persian DMs in the discourse.

\section{Review of related Literature}

The last 30 years have observed an explosion of articles and books on DMs, representing different theoretical frameworks and approaches for analysing them. The various terms used to call these features are illustrative of the diversity of functions DMs perform in the discourse. There is no general agreement on what to call these linguistic elements. They have been studied by different researchers under different labels to name a few: DMs (Schiffrin, 1987) (the term adopted in this study), Pragmatic Marker (Brinton, 1996; Fraser, 1996), Discourse Connectives (Blakemore, 1989), Discourse Operators (Redeker, 1991), Cue Phrases (Knott, 1993), Discourse Particles (Abraham, 1991; Kroon, 1995; Schourup, 1985), Pragmatic Particles (Ostman, 1983) and Pragmatic Expressions (Erman, 1987).

Among the prominent studies on DMs, Deborah Schiffrin's (1987) detailed analysis of 11 DMs in English could be regarded as the most comprehensive one. In her book, she provides a detailed analysis of 11 English DMs including: and, but, or, so, well, then, now, because, oh, y'know, and I mean. To Schiffrin, the coherence based approach towards DMs "combines interactional and variational approaches to discourse to analyse the roles of markers in co-constructed discourse" (Schiffrin et al., 2001, p. 60).

In the Persian context, Dabirmogadam's (2002) comparative study between 'but' from English and amma (but) from Persian might be a well-documented study. Though, some scholarly works have been conducted on DMs in a Persian context, the main concern of these studies has been the use of English DMs by non-native, Iranian students among which are the studies by Jalalifar and Hashemian (2010), Jalalifar (2008), Eslami and Eslami-Rasekh (2007) and Bahrami (1992). In their most recent research, Jalalifar and Hashemian (2010) investigated the frequency and functions of English DMs 'uh', 'well', 'you know' and 'I mean' in Iranian students' discourse in an interviewing setting. In his earlier study Jalalifar (2008) investigated the frequency and type of English DMs in the descriptive composition of 90 Iranian EFL students. Another study by Bahrami (1992) attempted to find out the effects of English DMs on the reading comprehension of Persian EFL learners. Eslami and Eslami-Rasekh (2007) emphasize on the facilitative effects of using English DMs on the listening comprehension of Iranian EFL students.

The most recent study by Noora and Amouzadeh (2015, p.91) examined the ways yani (it means) "loses its lexical and denotative meanings in favor of some new procedural -pragmatic meanings and functions".

\subsection{Features of Discourse Markers}

Although DMs cover a wide range of items from a variety of grammatical classes such as adverbs (frankly, well), lexical phrases (you know, I mean), conjunctions (but, since, and), filler words (oh), they share some features such as:

1. They are almost used in all languages (Lenk, 1998; Yilmaz, 2004).

2. They are syntactically independent (Schiffrin, 1987).

3. They are syntactically flexible, i.e. They may appear at the beginning, in the middle or at the end of an utterance. This flexibility contributes to their enormous usefulness and high frequency in discourse (Futji, 2001).

4. They do not affect the propositional meaning of utterance (Brinton, 1996; Schiffrin, 1987).

5. They make no contribution to the informational content of discourse.

6. They deal with the pragmatic aspects of discourse (Andersen, 2001; Fraser, 1990; Yilmaz, 2004).

7. They are meaningful but non-truth conditional (Lam, 2007, p. 29).

8. They are multifunctional (Fraser, 1990; Schiffrin, 1987; Yilmaz, 2004).

9. They are short, consisting of one to three syllables (Lenk, 1998).

\section{Theoretical Framework: Development of Brinton's Binary Model}

The present study makes use of Brinton's binary typology (1996) to classify Persian DMs functions. Due to the fact that Brinton's taxonomy has been proposed for English DMs, her model was developed to satisfy the detailed analysis of Persian DMs. The result was a model which would be compatible with the functions of Persian DMs. The proposed framework would deal with Persian DMs at two levels; macro and micro. At macro level the focus would be on DMs functions in the interpersonal and textual domains. Though the developed classification model for DMs in the textual and interpersonal realms comes close to Briton's model, it goes more elaborated at the micro level. At micro level, some sub-functions were developed to define the functions Persian DMs fulfil in the spoken discourse. The specification of categories to represent the functions DMs had in the data was a challenging task because of the multifunctionality of DMs ${ }^{\mathrm{i}}$. The resulting scheme consists of six categories for the Persian DMs functions at the textual level and seven categories for their functions at the interpersonal level. The developed categorization is based on the functions Persian DMs display in the data. Figure 1 illustrates Briton's model and figure 2 presents the developed model to define the functions Persian DMs fulfil in spoken discourse. 


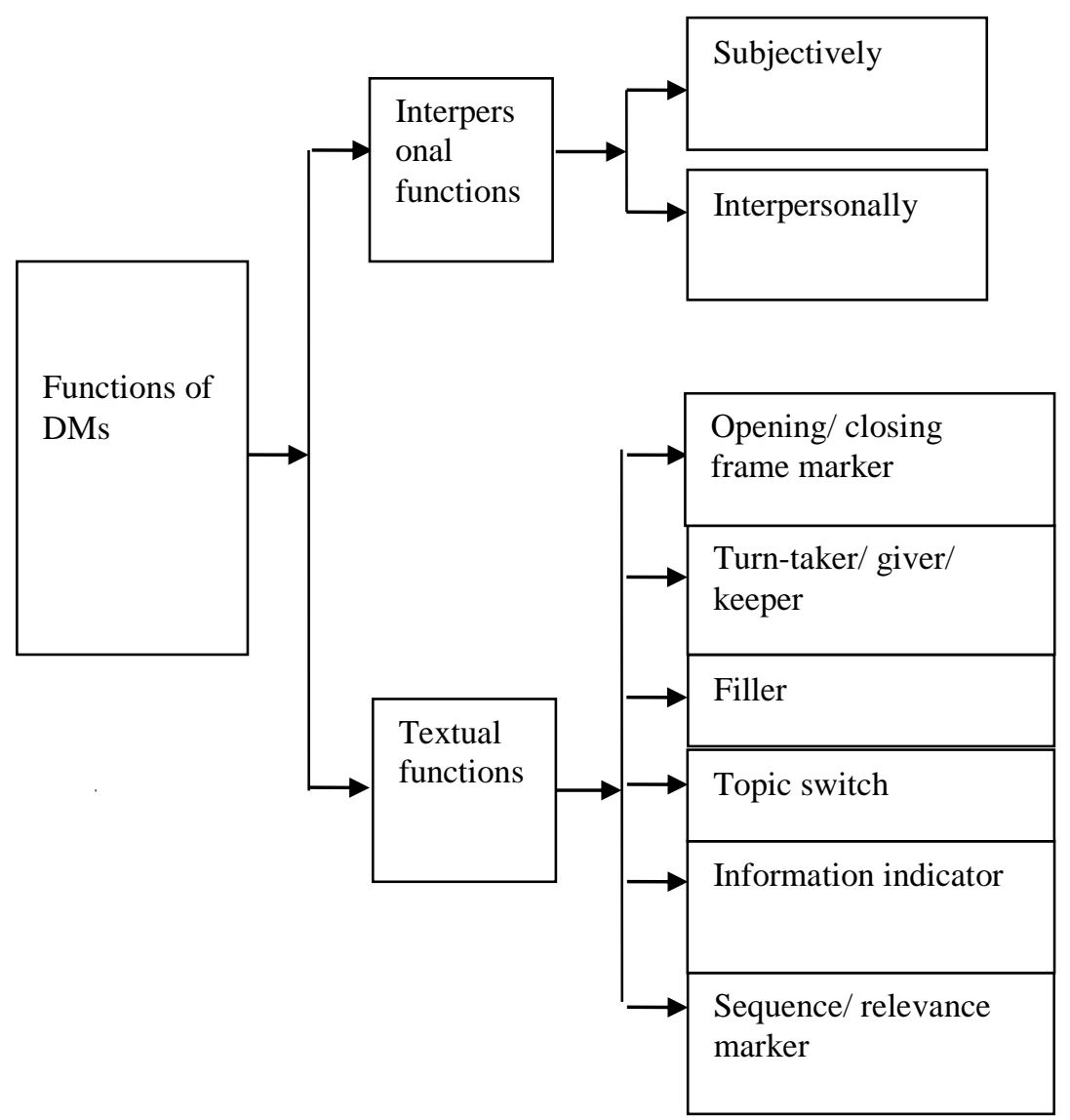

Figure 1. Brinton's Model of DMs functions (1996)

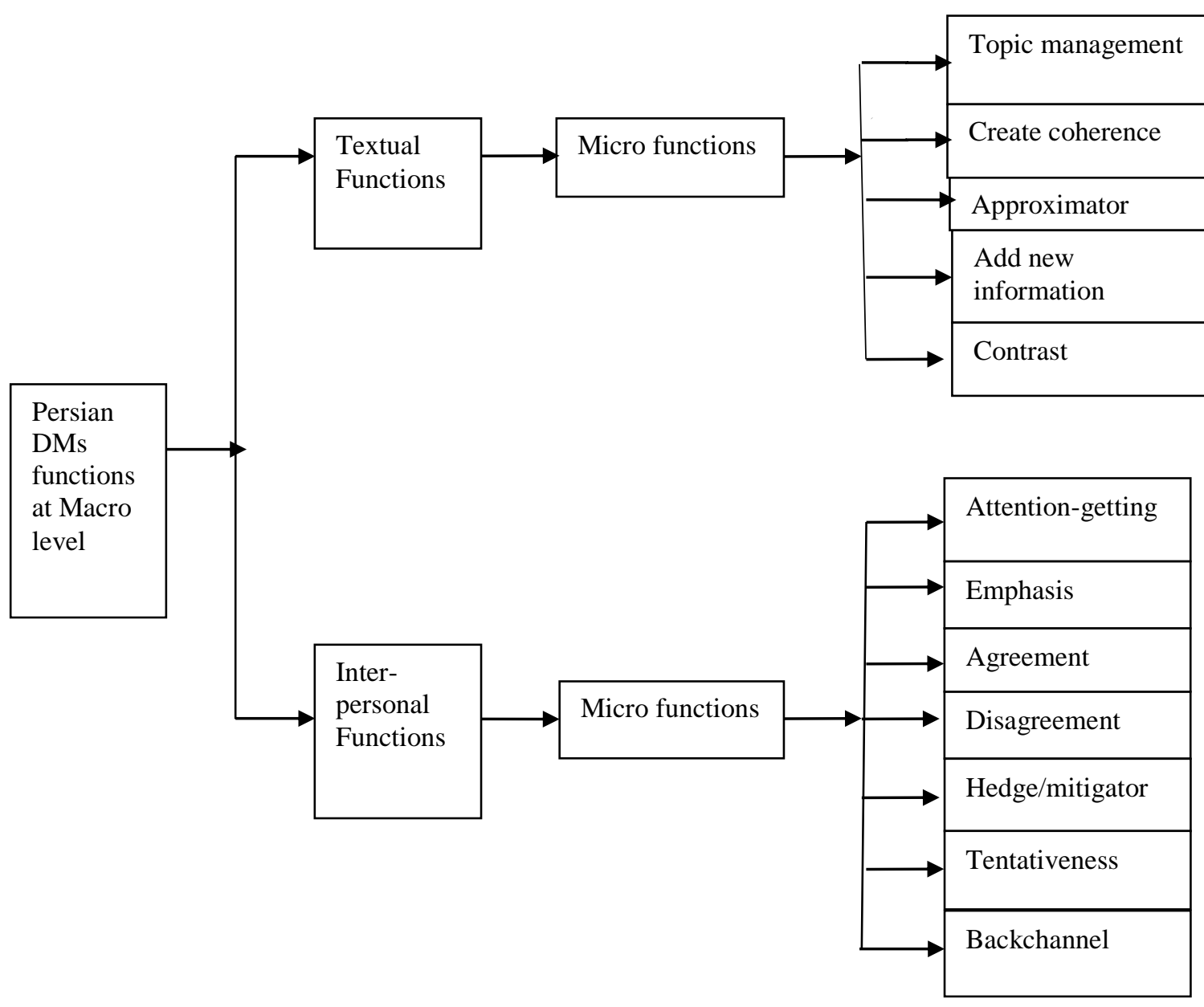

Figure 2. Developed Model for Persian DMs Classification (Based on Brinton's model, 1996) 
As illustrated in Figure 1, Briton's binary categorization of DMs functions was adopted in the present study. In accordance with this approach, all the instances of Persian DMs occurred in the recorded conversations were categorized under two macro functions, the interpersonal and textual functions. Nevertheless, a range of sub-functions had to be defined for Persian DMs on the basis of functions they had in the analysed corpus.

5.1 Textual Micro Functions

At the textual level, DMs deal with the textual resources in the speaker's repertoire to fulfil the following micro functions:

Elaboration: It encompasses 'reformulation/paraphrasing of the preceding proposition', 'speaker's self-correction/selfediting' and 'clarification through exemplification or explanation'.

Topic Management: A blanket term for topic initiation, topic shift, topic closure, floor holding, turn initiation, turn keeping and turn yielding practices.

Create Coherence: A strategy the speaker manipulates to construct coherence among segments of discourse.

Approximator: By breaking the line between past and present, DM approximates 'event time' and 'discourse time'.

Add new information: DM helps the speaker to denote new information, i. e., what succeeds is new information about the preceding proposition.

Contrast: DM guides the hearer to take the succeeding proposition as adversative to the preceding one and/or to display a different facet of the phenomenon.

\subsection{Interpersonal Micro Functions}

The seven micro functions defined for the Persian DMs at interpersonal micro level are:

Attention- getting: The addressee-oriented strategy used to attract the attention of the partner by highlighting some elements in the discourse.

Emphasis: Indicates the speaker's inclination to emphasize on a specific segment in his/her discourse.

Agreement: To show intimacy with the partner by agreeing on the discussed proposition.

Disagreement: Signalling partnership and engagement in interaction by occupying opposite stand.

Hedge/Mitigator: Helps the speaker to save the face for his/ her partner in the face- threatening speech act.

Tentativeness: It comprises 'reservation', 'doubtfulness', 'hesitation', and 'indecision' practices from the speaker.

Backchannel: As a reception marker, DM is used to provide the speaker with feedback and index the listenership.

\section{Research Design}

\subsection{Data Collection}

The data collection for the study started in the beginning of June 2011 and ended in November 2011. A personal audiorecorder with an internal microphone was used for recording conversations. The recordings were done either by the participants themselves or the researcher. Taking into account the "observer's paradox" (Labov, 1972, p. 113) and in order for the participants not to be distracted by the presence of the researcher, she was either absent or in those cases that she had to be present the attempt was to be less involved in the conversations. To collect the data for the study, in the first step the participants were asked for their permission to record their voice. The recordings were saved as sound tracks in the researcher's laptop. Then the recorded conversations were transcribed. In the next step, Persian DMs were identified in transcriptions followed by the specification of DMs functions.

\subsection{Participants}

The corpus, as shown in Table 1 comprises 14 conversations involving 22 male and 28 female Persian speakers. Segments of the 14 conversations were transcribed and analysed for the purpose of the present study. The estimated time of recorded conversations was five hours and eight minutes (348 minutes) in total from among which some segments were selected for the analysis. The conversations were basically natural, real-life interactions of Persian speakers conversing in informal situations.

The recordings were transcribed in full following Eggins and Slade's (1997) transcription system. After making a decision on the transcription system, the audio-recorded conversations were transcribed into Persian. The transcription phase was followed by the translation into English phase. The translation was neither word for word nor does it provide the literal meaning of the sentence. The attempt was to provide the reader with the pragmatic rather than the literal meaning of the message. In order to facilitate the reading of the transcribed texts, the DMs were italicized in both Persian and English transcriptions. Bearing in mind that DMs are untranslatable elements (Brinton, 1996), the researcher ensured that the English counterparts provided for some Persian DMs to be as close as possible to their meaning in the discourse they occur. The qualitative and quantitative analyses of the data were carried out on the English transcriptions. Care was taken that the translated versions to be compatible, syntactically and semantically, with the Persian transcriptions. Overlap, as a feature of natural talk often emerged in the recorded conversations. The sign == was used to indicate the point where two or more participants' talk overlaps. Another feature of spontaneous talk is a stretched word which happens for a variety of reasons (e.g. to buy time, slip of tongue). In this study the stretched words were presented by the repeated letters of the word (e.g. Todddaaayyy). The references to people, name of cities, countries, ethnical groups etc. are presented by the initial letter followed by hash \#\# in order to protect their privacy and anonymity (e.g. S\#\#, I\#\#). The emphasized words uttered by rising intonation were CAPITALIZED in the transcriptions (e.g. SURE). Attention was paid to capture all the actual words used by the speakers. However, in those cases when the stretches of talk were inaudible or incomprehensible because of external noise and/or low volume of the speaker's voice, the sign ( ) was used. In order to conceal the identity of the participants, the letters ' $M$ ' and ' $F$ ' were used to indicate male and female speakers respectively.

The range of conversations involves an array of situations including; conversation among immediate family members (e.g. wife and husband, mother and children), extended family members (e.g., aunt and nephew) and close friends. 
Except for three cases, all the conversations were recorded indoors. The particular dialect spoken by people living in Tehran, the capital of Iran has been the focus of the present studyii. Care was taken to ensure that the speech is spontaneous because this extemporaneous quality provides the necessary conditions for the use of DMs in discourse. The summary of recording excerpts including the number of participants, the setting, participants' age range and the length of conversations are presented in table 1.

Table 1. Summary of recording excerpts

\begin{tabular}{|c|c|c|c|c|c|c|}
\hline Corpus & $\begin{array}{l}\text { No. of } \\
\text { Participants }\end{array}$ & Male & Female & Age & Setting & $\begin{array}{l}\text { Length of } \\
\text { conversati } \\
\text { on }\end{array}$ \\
\hline Excerpt 1 & 2 & 1 & 1 & $\langle 22-27\rangle$ & home & 15 min. \\
\hline Excerpt 2 & 5 & 2 & 3 & $\mid\langle 25-32\rangle$ & home & $45 \mathrm{~min}$. \\
\hline Excerpt 3 & 2 & 1 & 1 & $\mid\langle 22-27\rangle$ & home & $35 \mathrm{~min}$. \\
\hline Excerpt 4 & 4 & 2 & 2 & $\mid\langle 27-32\rangle$ & home & $20 \mathrm{~min}$. \\
\hline Excerpt 5 & 3 & 2 & 1 & $\mid\langle 27-32\rangle$ & home & $10 \mathrm{~min}$. \\
\hline Excerpt 6 & 4 & 2 & 2 & $\mid\langle 22-42\rangle$ & home & $23 \mathrm{~min}$. \\
\hline Excerpt 7 & 3 & 1 & 2 & $\mid\langle 47-65\rangle$ & home & $27 \mathrm{~min}$. \\
\hline Excerpt 8 & 5 & 2 & 3 & $\langle 30-65\rangle$ & home & $40 \mathrm{~min}$. \\
\hline Excerpt 9 & 2 & 1 & 1 & $\langle 25-27\rangle$ & art exhibition & 17 min. \\
\hline Excerpt 10 & 6 & 2 & 4 & $|25-59\rangle$ & home & $20 \mathrm{~min}$. \\
\hline Excerpt 11 & 2 & 1 & 1 & $\mid\langle 59-65\rangle$ & car & $14 \mathrm{~min}$. \\
\hline Excerpt 12 & 2 & 1 & 1 & $\langle 35-57\rangle$ & home & 3 min. \\
\hline Excerpt 13 & 6 & 3 & 3 & $\langle 35-65\rangle$ & home & $42 \mathrm{~min}$. \\
\hline Excerpt 14 & 4 & 1 & 3 & $\mid\langle 25-59\rangle$ & cafe & $37 \mathrm{~min}$. \\
\hline Total & 50 & 22 & 28 & $\mid\langle 22-65\rangle$ & ----- & $348 \mathrm{~min}$. \\
\hline
\end{tabular}

\subsection{Frequency of Persian Discourse Markers}

An inventory of Persian DMs, identified via the qualitative analysis of the data, is presented according to the frequency of occurrence in Table 2.

Table 2. Persian DMs according to the frequency of occurrence.

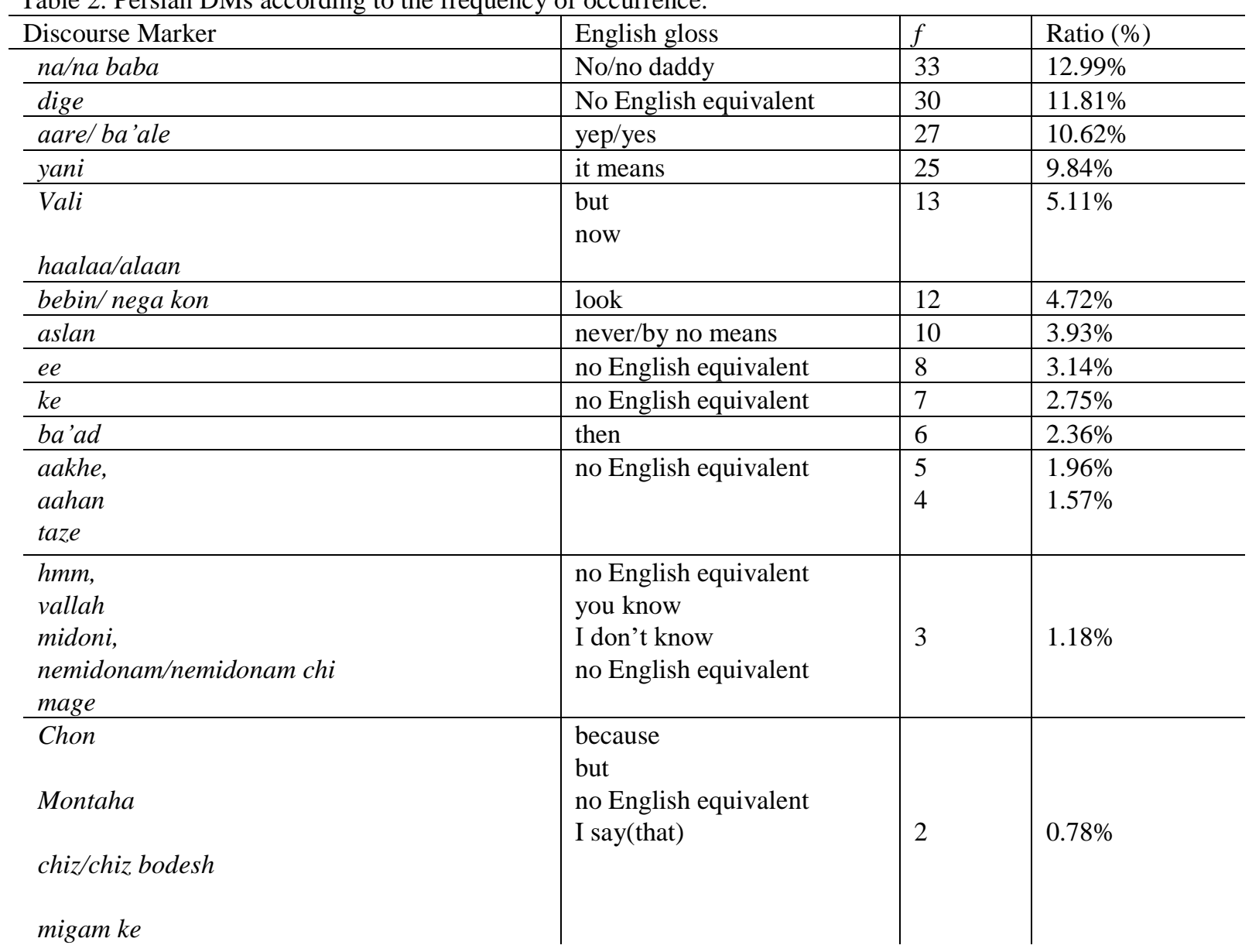




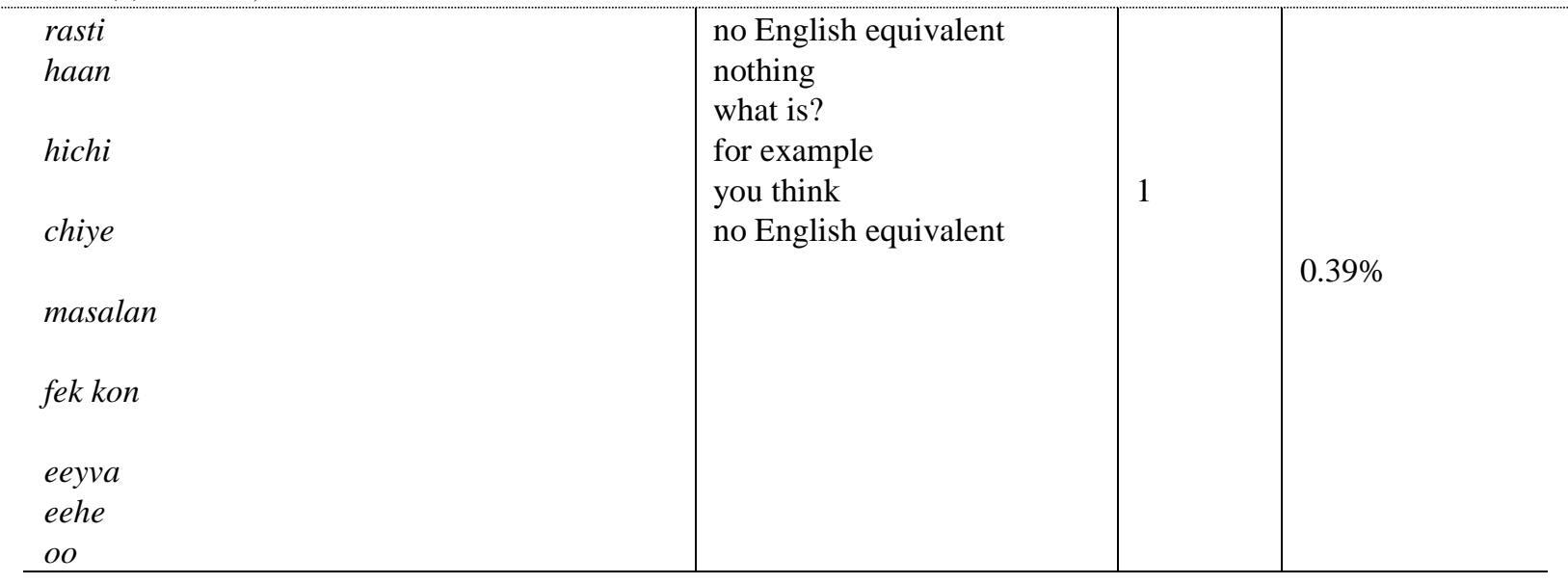

Table 2 provides the basic statistical information about Persian DMs used in 14 excerpts of various lengths as well as their percentages. It shows the overall frequency of DMs used by Persian men-women in casual conversations, arranged from the most frequent to the least frequent ones. There are altogether 34 tokens of Persian DMs with an overall 254 occurrences in the data. As Table 2 illustrates, the most frequent DMs identified in the corpora are; na/na baba (no/no daddy), dige (no English equivalent), aare/ba'ale (yeah/yes), yani (I mean), khob (well), vali (but), haalaa/alaan(now), bebin/nega kon (look), aslan (never, not at all), ee (no English equivalent), ke (no English equivalent) and $b a$ 'ad (then) among which 10 DMs have corresponding English expressions. As it can be inferred from Table 2 the DM na/ na baba (no/no daddy) occupies top rank in the frequency list of Persian corpora with the total of 33 (12.84\%) occurrences.

\section{Findings}

Persian is among the languages which allow its speakers the flexibility of selecting linguistic items from various categories to function as DM at above sentence level. The most common Persian DMs, their core functions and other functions they fulfil in the oral discourse are discussed in detail below. ${ }^{\text {iii }}$ The provided examples are excerpts selected from the corpus.

In terms of DMs positions in Persian discourse, it is observed that 135 uses of DMs are utterance-initial, 81 are utterance-medial and 21 occurred in the final position which indicates the Persian DMs strong proclivity to occupy the initial position. Apparently, this initial occurrence contributes to the smooth negotiation of turns in conversation by connecting the new turn to the previous discourse, mitigating the force of upcoming speech acts and helps the speaker to take turn and keep it. This finding is in line with the syntactic feature Brinton (1996) attributes to DMs when he asserts that the initial position is optimal for the DMs occurrence. The results further validates Muller's (2005, p. 5) account of DMs position as he states that DMs are supposed to appear "at the beginning of a discourse unit".

\subsection{Na/Na baba (no/no daddy)}

The results of the study show that in 14 casual conversations of various lengths, na/na baba (no/no daddy) is the most frequently used Persian DM with 33 occurrences out of 254 total numbers of DMs. As the qualitative analysis of the corpus suggests, the default function of na/na baba (no/no daddy) is to indicate the speaker's disagreement/nonalignment with the other speaker(s). Being the first linguistic element, this non-alignment function of na/na baba (no/ no daddy) in most cases is blended with the turn taking/turn initiating function it has in discourse. Apparently, among the functions that account for the presence of $n a / n a b a b a$ in Persian discourse are: to preface the dispreferred response in the speech act of question and answer, to initiate topic, act as turn-entry device, to initiate explanation and to get the attention of the addressee when used with rising intonation. A noteworthy difference between na (no) and na baba (no daddy) is that while the former can function at sentence level as a negative response to the adjacency pair of question and answer (as non-DM) as well as at discourse level with aforementioned functions (as DM), na baba (no daddy) only functions at discourse level and no non-DM meaning can be attributed to it. Indeed, the sense the word baba (daddy) implies is blurred in the meaning of $n a$ (no).

Despite the fact that in the process of Grammaticalization/Pragmaticalization "the syntactic information of a lexical item is sacrificed for the role of subjective form used for expressing speaker's view point" (Travis, 2006, p. 45), nevertheless it keeps some aspects of its characteristics when it is used as DM. In the case of na/na baba (no/ no daddy), the negative force that accompanies the speaker's disagreement/non-alignment shares the same aspects of negative response in question and answer adjacency pair.

Example 1

$$
\begin{aligned}
& \text { زن: من بحثم سر اينكه ( ) خودم ميدونستم كفتن كسانى كه فلوشيب دارن كل دوره } 2 \text { ساله. تازه ( ) من تازه آى اس آى داشتم. تازه شما هم ميكين ميكن }
\end{aligned}
$$

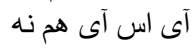

$$
\begin{aligned}
& \text { مرد: نه آى اس آى ميكن ولى در هر حال اكه داشته باشين شما مينو نين ( ) }
\end{aligned}
$$

$\mathrm{M}: n a$ (no) they say ISI vali (but) anyhow if you have got it, you can (inaudible)

The male speaker's non- alliance/ disagreement with his friend by inserting na (no) in the initial position is hedged by vali (but) in the medial position. 
Example 2

$$
\text { [خند: بعد روز مصاحبه كه رفتم كفتن } 2 \text { تا جابٍ سال اول داشته باثشين. آخه سال اول دانثجو، } 2 \text { تا جاب ،از آدم بدر در ميارن }
$$

$\mathrm{M}: n a$ (no) guys, do you know what is the point. See it has been written here down.Course mode and mix mode as well as high GPA.

The male speaker's use of $n a$ (no) in the initial position is for two purposes. On the one hand, it acts as turn-entry device employed by M. It signals that the producer is the new holder of the current turn. On the other hand, it is used as an attention- getting device. In this way $\mathrm{M}$ announces that what he is going to talk about is different and he desires to get the attention of the others.

Example 3

$$
\text { زن: ==نه بابا جيز إى كهنه== }
$$$$
\text { مرد: نه بابا كنسرو جِيه مو اد افزودنى داره }
$$

F: Na baba (no), out of date products

$\mathrm{M} 3==n a$ baba (no). What is the use of canned food. It contains some additives

Table 2 shows the occurrence of na /na baba (no/no daddy) in different positions in utterance.

Table 3. Distribution of na /na baba (no/ no daddy) in Persian discourse

\begin{tabular}{l|l|l|l|l|l}
\hline $\begin{array}{l}\text { Discourse } \\
\text { Marker }\end{array}$ & Initial & Medial & Final & Standalone & Total \\
\hline$n a / n a$ & 29 & 2 & 1 & 1 & 33 \\
$b a b a$ & $(88 \%)$ & $(6 \%)$ & $(3 \%)$ & $(3 \%)$ & \\
\hline
\end{tabular}

Table 3 shows the occurrence of na/na baba (no/ no daddy) in different positions of utterance. Apparently, na/na $b a b a$ (no/ no daddy) has a strong tendency to appear in initial position (88\%). It appears 33 times in the participants discourse with 29 turn-initial, 2 medial and 1 final occurrence. As a standalone element 1 occurrence is recorded for it.

\subsection{Dige (no English equivalent)}

As there is no non-DM occurrence of dige (no English equivalent) reported for it in the corpus, its status as a Persian DM is crystal clear. The qualitative analysis of the data suggests that the default function of dige (no English equivalent) is as 'emphatic marker'. Among those peripheral functions that DM dige serves in the Persian discourse are: to intensify the force of speech act, to mark the speaker's attempt in extracting information from his/her memory, to gain time, to close one topic and shift to another topic and to indicate the cognitive state of certainty the speaker tries to transfer to the hearer.

Example 1

$$
\begin{aligned}
& \text { مرد1: ......دختره بود با تو هم دوره شده بود. اعصابتو خرد كرده بود } \\
& \text { مرد2: ديوونم كرده بود ديخه ==وسط ار ايه حالا اينجا مثلا كلاسها... }
\end{aligned}
$$

M: she made me crazy dige (no English equivalent)==In the middle of presentation, haalaa (now) assume here is classroom....

The final occurrence of dige (no English equivalent) above has an emphatic function.

Example 2

$$
\text { مرد: بعد ديخه بعد جِيز كردا/IاI رفتيم فيلمو نحا كرديم }
$$

M: then dige then he did $e e$, we went together and watched the movie

In the above segment dige signals the male speaker's mental process of hesitancy. In addition, it helps him to fill the time gap to keep the floor to be able to elaborate more on the topic under discussion before yielding it to his interlocutor.

Example 3

$$
\begin{aligned}
& \text { مرد: بجه هاى ال\#\# خودشون ميكن " ما عيد فطرو شب عيد فطرو ميريم تو بارك ميخو ابيم كه فطريمون بيوفته يقه شهردارى" } \\
& \text { [خده] } \\
& \text { زن: ديكه اونا واقعا رو دست اس\#\# هاو ان\#\# ها بلن شدن }
\end{aligned}
$$

F: dige (no English equivalent) they are really worse than S\#\# and E\#\# 
As observed previously, the final occurrence of dige (no English equivalent) is considered as a typical position for it where it is used for emphasis. However, it seems that the position does not have a significant role in its function as emphatic marker. In other words, the initially occurring dige (no English equivalent) above by the female speaker is used for an identical function as well, i.e. emphasis.

The distributional pattern of DM dige (no English equivalent) is presented in the following table.

Table 4. Distribution of dige (no English equivalent) in Persian discourse

\begin{tabular}{l|lllll}
\hline $\begin{array}{l}\text { Discourse } \\
\text { Marker }\end{array}$ & Initial & Medial & Final & Standalone & Total \\
\hline dige & 5 & 10 & 15 & 0 & 30 \\
& $(17 \%)$ & $(33 \%)$ & $(50 \%)$ & $(0 \%)$ & \\
\hline
\end{tabular}

As illustrated in Table 4 although dige (no English equivalent) is not sensitive to the position in which it appears, it is used frequently in the final position $(50 \%)$ which accounts for the emphatic function it conveys. The non -occurrence of dige (no English equivalent) as a standalone element in Persian discourse accounts for the implication it has for demarcating the emphasis the speaker tends to convey and his/her inclination to highlight it for the hearer. To this end dige (no English equivalent) has to accompany the speaker's proposition and cannot be used as a standalone element. Furthermore the standalone dige (no English equivalent) in Persian discourse would convey different meaning which suggests its meaning at sentence level.

\subsection{Aare /Ba'ale (yeah/yes)}

An observation in terms of the frequency of aare/ba'ale (yeah/yes) as DM and as non-DM (positive response in question and answer pair) is that out of 29 tokens of aare/ ba'ale (yeah/yes)in the data 27 are used as DM (93\%). The grammaticalization process during which the propositional meaning of aare/ba'ale (yeah/yes) develops into pragmatic function at textual/interpersonal levels accounts for their frequent use. This diachronic development takes place when aare/ba'ale (yeah/yes) as a positive response to Yes/No question shifts to aare/ ba'ale (yeah/yes) as agreement marker at discourse level. As DM, the core function attributed to aare/ba'ale (yeah/yes) in this study is 'to encode the speaker's agreement' (the marker of listenership). Among the functions defined for aare /ba'ale (yeah/yes) in the corpus are: to shift the topic, as response-initiator, topic introducer, backchannel to signal agreement, to acknowledge the mutual agreement upon the subject, quotative marker to initiate the quotation, to register a sort of certainty to the speaker's own proposition (self-assertiveness), to take the floor, backchannel to index corroborant with the hearer, and to signal the speaker's state of mind from uncertainty to certainty.

Example 1

$$
\text { زن: آره آقاى دكتر. آقاى دكتر جند تا تا حالا مريض داشتين اينجورى؟== آقاى دكتر نمى شنوند }
$$

F: aare (yeah) aagaye (polite address form used for men) doctor, aagaye doctor how many patients with same problem do you have?==doctor doesn't hear me.

$\mathrm{M}:==$ for migraine?

F begins the discussion by addressing M. Aare (yeah) helps her to initiate the topic. In this way it signals turn taking and the onset of the topic that she opens up.

Example 2

$$
\text { زرد:؛ كنسرو جيه مو اد افزودنى داره مو آره افزودنى داره سرطان زاست }
$$

$\mathrm{M}:==$ What is the use of preserved food. They include some additives.

F: are (yeah) they contain additives. They are cancerous.

F's agreement with $\mathrm{M}$ in terms of the harmful effects of preserved foods is shown by aare (yeah) in the initial position of her turn.

The distributional flexibility of aare/ba'ale (yeah/yes) is displayed in Table.

Table 5. Distribution of aare/ba'ale (yeah/yes) in Persian discourse

\begin{tabular}{l|lllll}
\hline $\begin{array}{l}\text { Discourse } \\
\text { Marker }\end{array}$ & Initial & Medial & Final & Standalone & Total \\
\hline Aare/Ba'ale & 15 & 3 & 2 & 7 & 27 \\
& $(56 \%)$ & $(11 \%)$ & $(7 \%)$ & $(26 \%)$ & \\
\hline
\end{tabular}

As the table shows, DMs aare/ba'ale (yeah/yes) frequently occupies the initial position (56\%) which contributes to their function as agreement/alignment markers in the dialogical sense. Taking into consideration Schiffrin's statement that "conversation requires a delicate balance between the satisfaction of one's own needs and the satisfaction of other's needs" (1987, p. 100), the Persian speakers' use of aare/ba'ale as agreement marker could be interpreted as a care for 
their interpersonal needs as well as “other's needs”, (i.e., being considerate) which is a value in Iranian's culture. Iranians try to avoid self-promotion and they care about their addressees face especially when they are among close friends and family members. They resort to a variety of strategies to keep the face for their speech partner.

The second frequently used position by aare/ba'ale (yeah/yes) is standalone (26\%) which index their function as the backchannel maker. It signals listenership and contributes to the establishment of the relationship at interpersonal level.

\subsection{Yani (it means)}

The core function specified for yani (it means) in the data is 'elaboration' through clarification, adding new information and the reformulation of the preceding proposition. Another function of yani (it means) encompasses floor holding/turn keeping device through which the speaker tries to maintain the line of talk and hold the floor for his/her speech. Yani (it means) projects on the proposition via elaboration in order to prevent misunderstanding on the part of the hearer. As self-editing/self-correcting device it helps the speaker to repair his/her discourse by providing the hearer(s) with extra information. It further contributes to the truth-conditionality of the proposition by signalling that the upcoming discourse represents an explanation or elaboration either of something that has already been expressed or something that is going to be discussed. Yani (it means) marks the upcoming utterance as a reformulation of the preceding discourse by adding to the information the speaker has just given. The functions attributed to yani ( I mean) in the current study are almost compatible with the ones Noora and Amouzadeh (2015) propose in their study. They opine that yani (I mean) as a discourse/pragmatic marker can function as "conversational filler/ hesitation marker" and "mistake editor/ selfrepair". It may be used for elaboration, clarification, expansion, explanation, or reformulation of the preceding utterance as well (Noora and Amouzadeh (2015, p. 99).

Example 1

M: Sh\#\# yani (I mean) an industrial city==I mean that

$$
\begin{aligned}
& \text { زن:==يه ياداره حسابداريشه : }
\end{aligned}
$$

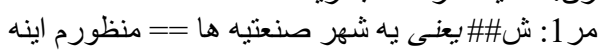

The male speaker uses yani (I mean) as a self- editing strategy. He attempts to provide the hearers with accurate and precise information about the city they are talking about. In this way the speaker clarifies what he has set out to state.

Example 2

F: All of them yani (I mean ) all of them are terrible

$$
\text { زن: يعنى همشون يكى از يكى بدنر }
$$

The medial occurrence of yani (I mean) and the duplicated phrase of 'all of them' contributes to the emphatic force F wishes to convey.

Table 6. Distribution of yani (it means) in Persian discourse

\begin{tabular}{l|lllll}
\hline $\begin{array}{l}\text { Discourse } \\
\text { Marker }\end{array}$ & Initial & Medial & Final & Standalone & Total \\
\hline yani & 9 & 16 & 0 & 0 & 25 \\
& $(36 \%)$ & $(64 \%)$ & $(0 \%)$ & $(0 \%)$ & \\
\hline
\end{tabular}

As shown in Table 6, the medial occurrence (64\%) and the initial position (36\%) are the preferred positions for yani (it means) which pertains to the function it serves in Persian discourse as 'elaborative marker'. There is no record for its occurrence as a standalone element or in the final position $(0 \%)$.

$7.5 \mathrm{Khob}$ (well)

Applying Brinton's 'Grammaticalization' concept to the diachronic process Persian DMs have undergone, it is observed that Khob (well) is a grammaticalized form of the adjective khob (/xu:b/ good). However, DM khob (well) differs prosodically and syntactically from its ancestor. Syntactically DM khob (well) can be used as a standalone element while khoob (good) is always followed by a noun it modifies (Persian grammar has the pattern of Noun+ Adjective). As an adjective, khoob (good) modifies a noun while DM khob (well) modifies a large segment of discourse and helps the hearer interpret the upcoming discourse. Scope broadening (Trougott, 1995) and "phonological reduction" (Travis, 2006, p. 44) are parts of the process of DM grammaticalization.

In the current study, turn initiation and turn taking are considered as the core functions of khob (well). Further functions that DM khob (well) fulfils in the data are: to onset an inquiry, to initiate a topic for discussion, to initiate the response, to take floor, to introduce explanation, to denote new information, as mitigator to save face for the addressee, to create coherence between two quotation, to signal an impending request for information and to emphasize a point.

Example 1

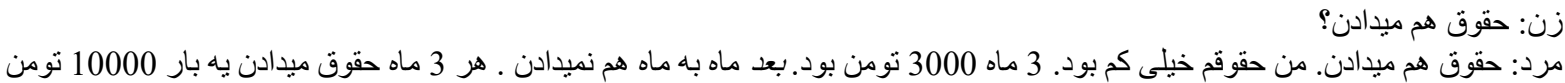

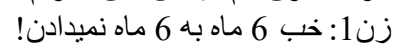

F: Were you paid salary?

M: I was paid. It was too little. 3000 for 3 months. $b a$ ' $a d$ (then) it was not paid every month. It was paid every other 3 months, 10000 Toman

F1: khob (well) it was not paid every other 6 month.

The initial khob (well) is employed by the female speaker to take turn. The default function of khob (well), the grammaticalization form of khoob (good), mainly in the initial position would function as the initiator of the discourse.

Example 2 
F: I started to become bald doctor. These (she shows her hair) are artificial. It is wig.

[laughing]

M: there was a lady, you could see her scalp

F: khob (well) I don't like to be the same. I wanna prevent.

Here khob (well) is used by $\mathrm{F}$ to introduce her explanations. In this way she provides the listeners with the rationale behind her insistence on the treatment offered by M (the doctor). Halliday and Hassan (1976, p. 269) refer to this use of $k h o b$ (well) as an introducer of "an explanatory comment".

The following is the distributional pattern of DM khob (well) in the present corpus.

Table 7. Distribution of khob in Persian discourse

\begin{tabular}{l|lllll}
\hline $\begin{array}{l}\text { Discourse } \\
\text { marker }\end{array}$ & Initial & Medial & Final & Standalone & Total \\
\hline khob & 22 & 2 & 0 & 1 & 25 \\
& $(88 \%)$ & $(8 \%)$ & $(0 \%)$ & $(4 \%)$ & \\
\hline
\end{tabular}

As Table 7 shows khob is profoundly (88\%) used in the initial position while no final occurrence is recorded for it. Thus, the initial position could be considered as a preferred position for khob (well) which contributes to its default function as topic initiator/turn taker.

\subsection{Vali (but)}

Given the fact that non-DM conjunction vali (but) when used as DM maintains many of its conjunctive features, distinguishing between these functions is not readily practical. In some ways vali (but) seems to be intermediary as a conjunctive element on the one hand and a marker of discourse on the other hand. In other words, its functions at sentence and discourse levels overlap where the implied contrast meaning is identical. In this study the core function specified for vali (but) at discourse level is to show adversative/contrast relationships between preceding and succeeding propositions. It helps the speaker to carry out the comparison job as well. Vali (but) marks the succeeding information as counter-expected. It contributes to the line of talk via elaboration as a counter point of view. By employing vali (but) the speaker is able to change the flow of talk in the opposite direction. Furthermore, it mitigates the face-threatening act of non-alignment by providing some contrastive features of the preceding proposition. In other words, a speaker can use DMs in the medial position to signal that there is an adversive relationship between the preceeding and succeding proposition.

Example 1

$\mathrm{F}:==$ sorry. I told "that one fits you much more".

$$
\text { زرد:==: ببخشيد من كفتم " اون يكى بيشتر بهت مارم مياد" }
$$

M: I have, vali (but) I do like to put on the worst one today.

The DM Vali (but) above creates an adversative relationship between two verbal phrases: 'daram' (I have) and 'dos daram' (I like) by adding an opposite dimension to the preceding proposition while the male speaker talks about his preferred dressing style.

Example 2

F: Has the intake been started?

M: They did intake vali (but) the head quarter is going to announce whether they need or not.

Vali (but) does not always do the mechanical work of contrasting propositions. In such cases as above it helps the speaker to continue the line of talk and add new information by providing a new facet of the proposition.

Table 8. Distribution of vali (but) in Persian discourse

\begin{tabular}{l|lllll}
\hline $\begin{array}{l}\text { Discourse } \\
\text { Marker }\end{array}$ & Initial & Medial & Final & Standalone & Total \\
\hline vali & 3 & 10 & 0 & 0 & 13 \\
& $(23 \%)$ & $(77 \%)$ & $(0 \%)$ & $(0 \%)$ & \\
\hline
\end{tabular}

As illustrated in Table 8 vali (but) frequently appears in the medial position which accounts for the contrast relationship it establishes between the preceding and succeeding propositions at local level. Likewise, the initial occurrence which according to the table is the second frequently used position for vali (but) pertains to the adversative sense it implies between propositions at global level. Owing to the function vali (but) has in discourse, no final and standalone usage are recorded for it. 
In the present research, turn initiation is the default function of haalaa/alaan (now). As approximators, haalaa/alaan (now) break the lines between past (event time) and present (discourse time). They are used to buy time/hold the floor as well. They contribute to the elaboration on topic via reformulation of the preceding proposition. Moreover, they contribute to the coherence between two propositions.

Example 1

$$
\begin{aligned}
& \text { زن: ==" همين كه صدمه نزنه زيره ياتو نكثه =="ميشه آدم خوب== }
\end{aligned}
$$

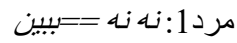

$$
\begin{aligned}
& \text { مرد 2: حالا نميخو اد بر ات خوبين بكنه كارى بكنه }
\end{aligned}
$$

M: haalaa (now) it is not necessary to help you, to do something for you.

The initial haalaa (now) helps M2 to take the floor in order to continue the flow of talk by elaborating on the topic. It fulfills turn taking and floor holding function simultaneously.

Example 2

$$
\begin{aligned}
& \text { زن: اونايى كه اونجان هو ایى اين آدمو داشته باشن خيلى هم آدم معتبريه ـ من تضمينش ميكنم آدم با سو اديه }
\end{aligned}
$$

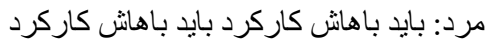

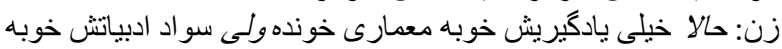

F: haalaa (now) he has aptitude for learning. He is architecture graduate vali (but) his literature knowledge is good.

The haalaa- prefaced (now) utterance above is the succession of the proposition the female speaker has already initiated. Haalaa (now) in this context serves the textual function of creating coherence among two propositions while she tries to satisfy the male speaker by providing some information about the eligibility of the fellow she has recommended for the new job position. The elimination of vali (but) shows that in medial position it contributes to the semantic meaning of the proposition and its omission will leave the utterance semantically damaged. Apparently the use of non-DM vali (but), in this context, helps the female speaker to refer to the existing contrast between the preceding and succeeding propositions.

Table 9. Distribution of haalaa/ alaan (now) in Persian discourse

\begin{tabular}{l|lllll}
\hline $\begin{array}{l}\text { Discourse } \\
\text { Marker }\end{array}$ & Initial & Medial & Final & Standalone & Total \\
\hline $\begin{array}{l}\text { Haalaa/ } \\
\text { alaan }\end{array}$ & 9 & 4 & 0 & 0 & 13 \\
\hline
\end{tabular}

With reference to Table 9, haalaa/ alaan (now) in the initial and medial occurrences are the only recorded positions, while no use in the final position or as a standalone element is found for them.

\subsection{Bebin (look)}

Although bebin (look), the imperative verb forms, are not necessarily an instruction from the speaker to make the hearer to see/look at something, what is significant about these DMs is that they bear some resemblance to their grammatical function. Thus, the function of bebin (look) as attention getter/discourse highlighter could be traced back to the sense they carry as the imperative verb form at sentence level. It is therefore not their lexical meaning rather their grammatical function to get the attention of the addressee that is borrowed for discourse work and is considered as the core function for them in this study. In addition to their function as attention-seeker, bebin(look) is used to highlight some elements in the turn the speaker is about to take, to foreground the upcoming proposition, to create interpersonal solidarity, to bracket and mark the upcoming talk as being salient and to seek the hearer's attention.

Example1

$$
\text { زرد: معدل فوقمون خوب. اينجا درس خونديم. مقاله داديم } 2 \text { نا }
$$

F: bebin (look) it has nothing to do with the school. I, by chance, was talking with == a professor of mine.

The use of bebin (look) as a discourse highlighter signals the saliency of information. The linguistic form of bebin (look/see) is not based on a 'seeing' root per se. It is purely an attention- getting marker. The highlighting function of bebin (look) as Fairbank (2009) states has the effect of confirming a pre-existing belief or condition put forth by the speaker, something that perhaps has not been already appreciated or observed by interlocutors. The attention-getting function of bebin (look) is similar to the function 'look' performs in English discourse.

Example 2

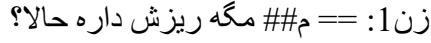

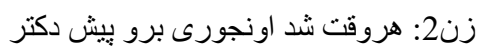

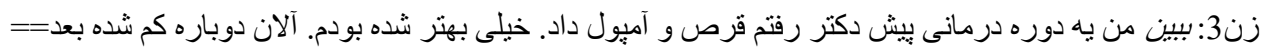

F: bebin (look) I was under medication. I took some pills and injection. It was much better.

The hearer-oriented initially occurring bebin (look) in the above is not only used as a device to foreground the upcoming information but also to create solidarity between the speaker and addressee(s). 
Table 10. Distribution of bebin (look) in Persian discourse

\begin{tabular}{l|lllll}
\hline $\begin{array}{l}\text { Discourse } \\
\text { Marker }\end{array}$ & Initial & Medial & Final & Standalone & Total \\
\hline Bebin & 10 & 1 & 0 & 1 & 12 \\
& $(84 \%)$ & $(8 \%)$ & $(0 \%)$ & $(8 \%)$ & \\
\hline
\end{tabular}

Table 10 illustrates the position of bebin (look) in Persian discourse. As it could be read, there is no record for the final occurrence of bebin (look). Functioning as an attention-getting marker bears out the final absence of bebin (look) in the discourse.

7.9 Aslan (never/by no means)

In the literal sense, as an adverb of frequency, aslan (never) acts on specific elements of the sentence in a way that aslan (not at all/by no means) as DM does not. In the recorded data, there is no token of the literal use of aslan (never) as an 'adverb of frequency'. A noteworthy fact is that in the grammaticalization process aslan (never/not at all) as DM has changed to the extent that it must be considered as a 'homonym' to aslan (not at all/by no means)and as an adverb of frequency. Through the grammaticalization process, aslan (never) maintains its prosodic properties but loses the semantic function as an adverb of frequency. The default function defined for aslan (by no means/not at all) in this study is the emphasis on the propositional meaning of the discourse'. It is used to strengthen a particular point made in the proposition. Furthermore, it contributes to the maintenance of the flow of talk as filler, to initiate turn and as a selfediting device through reformulation of the preceding proposition. It contributes to the turn-taking effort of the speaker as well.

Example 1

$$
\begin{aligned}
& \text { مرد: آقا بنده دوس ندارم. اصلا نميبونم دوست دارم كونى بيوشم دوس دارم نمى دونم فلان بيوشم . }
\end{aligned}
$$

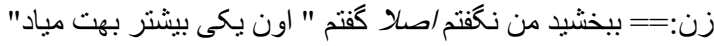

$\mathrm{F}:==$ sorry I didn't say, aslan (never/not at all) I told "that one fits you much more".

The medially used aslan (never/ not at all) functions as a self-editing device employed by the female speaker. It has a clarifying function but not via exemplification. Apparently, by using aslan (never/not at all) the female speaker attempts to reformulate her proposition.

Example 2

$\mathrm{F}: n a(n o)$ actually they are not from I\#\#. They are from N\#\#.

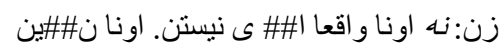

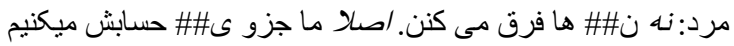

$\mathrm{M}$ : na (no) N\#\#ies are different. Aslan (not at all) we are considering N\#\# as a part of Y\#\#.

M1's disagreement with M2 is conveyed by the initial occurrence of na (no) in the first segment. In the same line aslan (not at all/ by no means) in the initial position of segment 2 has emphatic function at textual level.

Table 11. Distribution of aslan (never/not at all) in Persian discourse

\begin{tabular}{l|lllll}
\hline $\begin{array}{l}\text { Discourse } \\
\text { Marker }\end{array}$ & Initial & Medial & Final & Standalone & Total \\
\hline aslan & 5 & 5 & 0 & 0 & 10 \\
& $(50 \%)$ & $(50 \%)$ & $(0 \%)$ & $(0 \%)$ & \\
\hline
\end{tabular}

From Table 11, it is inferred that aslan (by no means/not at all) appears in the initial and medial positions equally. However, there is no record for its final and standalone occurrence.

\section{Concluding Remarks}

In their everyday interactions, Persian speakers frequently use with ease lexical items such as; na/na baba (no/no daddy), bebin (look), aare (yeah), haalaa (now), vali (but), aslan (by no means) and dige (no English counterpart). However, when it comes to defining and specifying their discoursal functions, they remain "mystery particles" (Longacre, 1976, p. 468). While Persian linguistics focuses on the propositional content of the above mentioned lexical items at sentence level e.g., na (no) and aaree (yeah) as responses to question and answer adjacency pair, bebin (look) as an imperative verb form, vali (but) as conjunction, haalaa/alaan(now) as temporal deictic, the pragmatic functions they perform at discourse level have been neglected.

This paper was an attempt to scrutinize the semantic and pragmatic meanings of the most common Persian DMs with their various functions at the textual and interactional levels in spoken language. Furthermore, it discussed the possible path of grammaticalization some of Persian words went through to function as DM.

In terms of Persian DMs positions in discourse, it is observed that 135 uses of DMs are utterance-initial, 81 are utterance-medial and 21 occurred in the final position indicative of Persian DMs strong proclivity to occupy in the initial position. Apparently, this initial occurrence contributes to the smooth negotiation of turns in conversation by connecting the new turn to the previous discourse, mitigating the force of upcoming speech acts and helps the speaker to take turn and keep it. This finding is in line with the syntactic feature Brinton (1996) attributes to DMs when he asserts that the initial position is optimal for the DMs occurrence. The results further validates Muller's (2005, p. 5) account of DMs position as he states that DMs are supposed to appear "at the beginning of a discourse unit". 


\section{Implications/ Contributions of the Study}

Although this study presents the speech of a small group of the Persian community, it could be of use in indexing direction for other researches in the area of oral Persian discourse in the first place. Secondly, given the fact that the development of the structured corpus is a requirement for any given language, the data collected for the present study could be used as a part of Persian Spoken Language Corpus (PSLC). It provides the scholars, who are dealing with oral discourse in Persian and seeking for the patterns of actual language usage, with authentic materials.

Thirdly, the data-driven functional typology developed for Persian DMs in the present study has implications for Persian discourse analysts in describing DMs and interpreting their functions. Indeed the proposed list of Persian DMs (see Table 2) invites some challenging comparisons for those researchers who study DMs and seek their functions in discourse. In a language like Persian where no documented list of DMs is available, the suggested list of DMs can act as the 'North Star' that is used for navigating related studies. Furthermore, the already growing cross-linguistic body of studies on DMs can make use of the findings of the present study to widen our understanding of their discourse behaviour to find out the similarities/differences among languages.

Inasmuch as Persian DMs have been absent in the dictionary entries and grammar books, the results of this study provide a new approach towards understanding their significances in language especially in spoken discourse. Moreover, it is hoped that the findings of the current study is used as a yardstick in the learning and teaching of Persian language. The results of this study could be used for raising learner's pragmatic awareness in the use of DMs in the pedagogical sense. One of the manifestations of the language learners' discourse competency is in their ability to use DMs appropriately and effectively. As Fraser (1988, p. 22) argues "the absence of the DM does not render a sentence ungrammatical and/or unintelligible. It does, however, remove a powerful clue about what commitment the speaker makes regarding the relationship between the current utterance and the prior discourse." Therefore, the pedagogical contribution of this research would be for course and syllabus designers. They could corporate the findings in the content of textbooks by focusing on spoken discourse and the significance of DMs in fulfilling the speakers' intended meaning.

\section{References}

Abraham,W. (Ed.) (1991). Discourse Particles in German: How does their illocutive force come about? Amsterdam: John Benjamins.

Alami, M. (2015). Pragmatic Functions of Discourse Markers: A review of related Literature. International Journal on Studies in English Language and Literature, 3(3), 1-10.

Andersen, G. (2001). Pragmatic Markers of Sociolinguistic Variation: A Relevance -theoretical approach to the language of adolescent. Amsterdam: John Benjamins.

Bahrami, A. (1992). English Discourse Markers and their impact on the reading comprehension of Persian EFL students. M.A. Thesis. Allameh Tabataba'i University. Tehran, Iran.

Blakemore, D. (1989). Denial and contrast: A relevance theoretical analysis of 'but'. Linguistics and Philosophy, 12, 15-37.

Bolden, G.B. (2008). Reopening Russian conversations: The discourse particle-to and the negotiation of interpersonal accountability in closings. Human Communication Research, 34, 99-136.

Brinton, L. (1990). The development of discourse markers in English: Historical linguistics and philology. In J. Fisiak, (Ed.)Trends in Linguistics, Studies and Monographs( 45-71), Berlin and New York: Mouton de Gruyter, 45-71.

Brinton, L. (1996). Pragmatic Markers in English: Grammaticalization and Discourse Functions. Berling and New York: Mouto de Gruyter.

Brinton, L. (2008). The Comment Clause in English Syntactic Origins and Pragmatic Developments (Studies in English Language). Cambridge: CUP.

Dabirmoghadam, M.(2002). Discourse Markers. Pazhuhesh-E- Zabanha-ye Khareji, 12, 55-76.

Eggins, S. and Slade, D. (1997). Analyzing Casual Conversation. London: equinox.

Erman, B. (1987). Pragmatic Expressions in English: A study of 'you know', 'you see' and 'I mean' in face-to-face conversation. Stockholm: Almqvist and wiksell.

Eslami, Z.R. and Eslami-Rasekh, A. (2007). Discourse markers in academic lectures. Asian EFL Journal, 9(1), Article 2.

Fraser, B. (1990). An approach to discourse marker. Journal of Pragmatics, 14, 383-395.

Fujita, Y. (2001) Functions of discourse markers in Japanese. Texas Papers in Foreign Language Education, 6(1), 147162.

Goddard, A. and Meanpatterson, L. (2000).Language and Gender. London: Rutledge.

Halliday, M., \& Hasan, R. (1976). Cohesion in English. Harlow: Longman. 
Jalalifar, A.R. (2008). Discourse markers in composition writing: The case of Iranian learners of English as a foreign language. English Language Teaching, 1(2), 114-122.

Jalalifar, A. R., \& Hashemian, M. (2010). Uh, well, You know, I mean it: Discourse Markers use by non-native students in Interview settings. Iranian EFL Journal, 6(1), 101-122.

Knott, A. (1993). Using cue phrases to determine a set of rhetorical relations. In O. Rambow, (Eds.) Internationality and Structure in Discourse Relations: Proceedings of the ACL SIGGEN workshop.

Labov, W. (1972). Sociolinguistic Patterns. Philadelphia: University of Pennsylvania Press.

Lenk, U. (1998). Discourse markers and global coherence in conversation. Journal of Pragmatics, 30(2), 245- 257.

Muller, S. (2005). Discourse Markers in Native and Non-native English Discourse. Amsterdam: John Benjamins.

Noora, A. and Amouzadeh, M. (2015). Grammaticalization of Yæni in Persian. International Journal of Language Studies (IJLS), 9(1), 91-122.

Ostman, J.O. (1983). You Know: A Discourse Functional Approach. Amsterdam: John Benjamins.

Quirk, R., Greenbaum, S., Leech, G., and Svartvik, J. (1985). A Comprehensive Grammar of the English Language. New York: Longman.

Redeker, G. (1991). Review article: Linguistic markers of discourse structure. Linguistics, 29(6), 1139-1172.

Schiffrin, D. (1987). Discourse Markers. Cambridge: CUP.

Schiffrin, D. Tannen, D. and Hamilton, H.E. (2001). The Handbook of Discourse Analysis. London: Blackwell.

Schourup, L. (1985). Common Discourse Particle in English Conversation : like, well, y'know. Birmingham: Garland.

Stenstorm, A.B.(1994). An Introduction to Spoken Interaction. London: Longman.

Yilmaz, E. (2004). A Practical Analysis of Turkish Discourse Markers: yani, iste and sey. PhD Thesis. Istanbul: Middle East Technical University.

\section{Notes}

${ }^{\text {i }}$ There was no one- to- one relationship between DMs forms and functions, i. e., a certain DM could fulfil variety of functions in discourse while a particular function could be expressed by different DMs.

ii The emerging challenge here was that many dialects are generally known as Persian. While many speakers from other cities in Iran refer to their language as Persian, the term 'Persian' in this study refers to the form of language spoken in Tehran (capital of Iran). Thus, it is necessary to acknowledge that in this study the term 'Persian' is not used to refer to a group of related dialects nor are the Persian DMs identified in this study representative of the DMs in other Persian dialects.

iii The DM tokens that comprise less than three per cent of the total number of DMs were excluded from discussion. 